\title{
Establishment of a semi-selective method for the detection of Sclerotinia sclerotiorum in dry bean and soybean seeds ${ }^{1}$
}

\author{
Vivian Hikari Kawasaki²*, José da Cruz Machado
}

\begin{abstract}
The objective in this work was to improve the existing methodology for the detection of Sclerotinia sclerotiorum in dry bean and soybean seeds through the use of water restrictors in place of 2,4-dichlorophenoxyacetic acid, in PDA substrate containing bromophenol blue and antibiotics (Neon-S). Firstly, the effects of the water restrictors mannitol, sodium chloride, and polyethyleneglycol (PEG6000) at different osmotic potentials were evaluated on the mycelial growth of S. sclerotiorum isolates and on the radicle protrusion of seeds of the species studied. The use of water restrictors with osmotic potentials of up to -0.5 MPa for PEG and -1.0 MPa for mannitol and sodium chloride did not affect the mycelial growth of the isolates tested, and proved to be satisfactory to inhibit the radicle protrusion of the seeds tested. In the second stage of this work, alternating light and continuous darkness were tested in the detection of fungus in the seeds of both species by the modified Neon method. The methodology composed by solid medium PDA, bromophenol blue (100 ppm), chloramphenicol (50 ppm) and water restrictor mannitol $(-1.0 \mathrm{MPa})$ at a temperature of $20^{\circ} \mathrm{C}$ with incubation in darkness, proved to be effective and reliable in the detection of that pathogen in routine analysis laboratory.
\end{abstract}

Index terms: seed pathology, seed health tests, white mold, Phaseolus vulgaris, Glycine max.

\section{Estabelecimento de um método semi-seletivo para detecção de Sclerotinia sclerotiorum em sementes de feijão e soja}

\begin{abstract}
RESUMO - O objetivo neste trabalho foi definir uma metodologia de detecção de Sclerotinia sclerotiorum em sementes de feijão e soja por meio da utilização de restritores hídricos, em substituição ao uso de ácido 2,4-diclorofenoxiacético, em substrato agar sólido contendo azul de bromofenol e antibióticos (Neon-S). Primeiramente, foram avaliados os efeitos dos restritores hídricos manitol, cloreto de sódio e polietilenoglicol, em diferentes potenciais osmóticos, no crescimento micelial de isolados de Sclerotinia sclerotiorum e na protrusão das radículas das sementes em estudo. O emprego de restritores hídricos com potenciais osmóticos acima de -0.5 MPa para PEG e de -1.0 MPa para manitol e cloreto de sódio não afetou o crescimento micelial dos isolados testados e proporcionou inibição satisfatória da protrusão radicular das sementes em estudo. Na segunda etapa deste trabalho, os regimes alternância de luz e escuro contínuo foram testados na detecção do referido fungo nas sementes em estudo. A metodologia de detecção semi seletiva de S. sclerotiorum com substrato BDA, azul de bromofenol (100ppm), cloranfenicol (50 ppm) e o restritor hídrico manitol (-1.0 MPa), sob temperatura de $20^{\circ} \mathrm{C}$, incubação na ausência de luz, revelou-se mais eficaz e seguro para a detecção do referido patógeno em análises de sanidade de rotina.
\end{abstract}

Termos para indexação: patologia de sementes, teste de sanidade, mofo branco, Phaseolus vulgaris, Glycine max.

\section{Introduction}

Soybean and dry bean crops are of great importance in Brazil, and are cultivated in a large area of the country. As a consequence of an increased demand for more food and commodities destined for internal consumption and export, the cultivating areas of both crops have been experiencing a great increase in recent years that has led to several problems.

Submitted on 12/04/2012. Accepted for publication on 08/01/2013.

${ }^{2}$ Universidade Federal de Lavras, Caixa Postal 3037, 37200-000 - Lavras, MG, Brasil
Among the factors limiting such cultivation are the diseases that occupy an outstanding position for causing serious losses in terms of yield reduction and contamination of the cultivating areas. The white mold disease, which is caused by Sclerotinia sclerotiorum, is considered as one of the most threatening and impacting diseases in both crops in Brazil in recent years.

White mold can be spread by seeds and the sclerotia that are present in seed lots. These are some of the most effective

${ }^{3}$ Departamento de Fitopatologia, Laboratório de Patologia de Sementes, UFLA, Caixa Postal 3037, 37200-000 - Lavras, MG, Brasil.

*Corresponding author: <vivikawasaki@gmail.com> 
ways to spread the inoculum over long distances (Boland and Hall, 1994, Peres et al., 2002). Through those sclerotia, the fungus can survive in soil for long periods under adverse conditions (Adams and Ayers, 1979).

Because of the rapid dissemination of white mold in Brazil in recent years a tolerance level of zero for the presence of sclerotia of S. Sclerotiorum in seed samples of dry bean, soybean, cotton, and sunflower was proposed by the Brazilian Ministry of Agriculture. However, the association of the pathogen with the seeds of host species as dormant mycelium raised the need to develop a new method for the detection of the fungus in infected seeds. Such a method, named Neon, consists of the incubation of seeds on a semi-selective agar substrate, PDA, amended with bromophenol blue and antibiotics, with the medium acidity adjusted to pH 4.7 (Neon) (Peres et al., 2002, Napoleão et al., 2006). The principle of that method is based on the change of color of the substrate from blue to yellow as the result of the oxalic acid action produced by the pathogen around the seeds (Steadman et al., 1994). The new modification of the method was proposed by Napoleão et al . (2006) to inhibit the germination of soybean and dry bean seeds during the incubation period by adding 2,4-dichlorophenoxyacetic acid in to the PDA substrate. However, it is worthwhile to register that the use of 2,4-D in routine tests for seed analysis is questionable because of the high risks that this product may cause not only to the development of the fungus but also because its toxic effects to humans working in routine seed analysis in laboratories (Coutinho et al., 2001).

In relation to the light regime adopted in the health test to detect $S$. sclerotiroum in dry bean and soybean seeds, there is no conclusive information about the most appropriate regime for the biological method that is currently used in some seed health laboratories.

In this work, the objective was to make some adjustments in the semi-selective agar method in order to make this procedure more reliable and accurate for the routine seed samples analysis. The central focus that is addressed is the replacement of 2,4-D by water restrictors and checking the most adequate light regime for the detection of S. sclerotiorum in dry bean and soybean seeds.

\section{Material and Methods}

\section{Origin of S. sclerotiorum isolates}

For this study, four strains of S. sclerotiorum were used. One strain was isolated from dry bean seeds produced in Lavras-MG (ISF), one isolate was recovered from cotton seeds produced in Luziânia-GO (ISA), and the two other isolates were recovered from soybean seeds, one from Cristalina-GO (ISS1) and the other from Lavras-MG (ISS2).

\section{Preparation of the substrates}

The substrate of the biological method used in this work was composed by PDA amended with chloramphenicol, at $50 \mathrm{ppm}$ concn and bromophenol blue at $100 \mathrm{ppm}$ concn. Modifications of that medium which were compared in this study consisted of the addition of 2,4-dichlorophenoxyacetic acid (2,4-D) at the concentration of $50 \mathrm{ppm}$, named by Napoleão et al. (2006) as Neon-S and the addition of water restrictors, mannitol, sodium chloride $(\mathrm{NaCl})$, and polyethylene glycol (PEG6000), herein named as Neon-R. The water restriction compounds were tested with different osmotic potentials, which were determined by the software SPPM (Michel and Radcliffe, 1995). The following osmotic potentials were used $-0.6 ;-0.8 ;-1.0 ;-1.2$ and $-1.4 \mathrm{MPa}$ for mannitol and $\mathrm{NaCl}-0.1 ;-0.3 ;-0.5 ;-0.7$ and $-0.9 \mathrm{MPa}$ for PEG6000. Due to the solubility property of PEG6000 in agar, it was necessary to use the same solution diluted in distilled water, depending on the concentrations required and pouring $10 \mathrm{~mL}$ of this preparation onto Neon medium (PDA, chloramphenicol and bromophenol blue), previously solidified in the dishes.

All components of the substrates used were added to the medium before autoclaving. After preparation, the culture media were autoclaved at $121^{\circ} \mathrm{C}$ for 20 minutes.

Evaluation of the effect of water restrictors added to agar substrate of basic Neon method on the mycelial growth of Sclerotinia sclerotiorum

The effects of water restriction on the mycelial growth of S. sclerotiorum were evaluated in the semi-selective medium containing bromophenol blue, chloramphenicol and the water restrictors: mannitol, $\mathrm{NaCl}$ and $\mathrm{PEG}$, at a different osmotic potential as indicated and prepared previously. Basic Neon-B (PDA without seed germination inhibitors) and Neon-S (PDA containing bromophenol blue, and chloramphenicol with 2,4$\mathrm{D}$ acid) were used as reference treatments.

After autoclaving, all the media were transferred $(15 \mathrm{~mL})$ onto Petri dishes, $9 \mathrm{~cm}$ in diameter. Discs of $5 \mathrm{~mm}$ were cut at the edge of $S$. sclerotiorum colonies, 5 days old, from each of the four isolates and transferred to the center of each dish, and five dishes were used as replicates. The dishes were distributed in an incubation chamber (BOD) with a 12-hour photoperiod at $20^{\circ} \mathrm{C}$.

Measurements of mycelial growth were made daily by taking two orthogonal diameters of the developed colonies of the $S$. sclerotiorum isolates on the back side of each dish until a colony had reached the edge of the dish. The mycelial growth rate (ICM) was determined according to the formula ICM $=\mathrm{C}_{1} / \mathrm{N}_{1}+\mathrm{C}_{2} /$ $\mathrm{N}_{2}+\ldots+\mathrm{C}_{\mathrm{n}} / \mathrm{N}_{\mathrm{n}}$ where " $\mathrm{C}$ " is mycelial growth in each " $\mathrm{N}$ " 
number's days. The statistical regression analysis was performed using the software Sisvar (Ferreira, 2003) and the experiment was conducted using a completely randomized design and a factorial of five water potentials for four strains in each solute.

Evaluation of the effects of water restriction on the root protrusion of dry bean and soybean seeds

The effects of water restriction on the root protrusion of seeds were assessed in relation to the solute water potentials, as described earlier. The substrate in this trial consisted of three pads of filter paper, $15 \mathrm{~cm}$ diameters, sterilized and moistened in diluted Neon medium, containing water restrictors in the same osmotic potentials described in the previous experiment. The filter paper pads were placed in Petri dishes and to each dish forty seeds being distributed on the top. All dishes were placed in an incubation chamber with a temperature of $20^{\circ} \mathrm{C} \pm$ $2{ }^{\circ} \mathrm{C}$ and photoperiod of 12 hours for 7 days.

The evaluation consisted of counting germinated seeds. Seed germination was based on the visible root emission (length longer than $1 \mathrm{~mm}$ ).

Detection of Sclerotinia sclerotiorum in dry bean and soybean seeds by the Neon method modified with water restriction (Neon-R)

From the results of the previous experiments 1 and 2, comparisons were made between the standard biological method and its modifications. The biological method osmotically modified were tested using mannitol (-1.0 MPa), $\mathrm{NaCl}(-1.0 \mathrm{MPa})$ and PEG (-0.5 MPa).

\section{Procedure to infect seeds with Sclerotinia sclerotiorum}

To obtain seeds of bean and soybean artificially infected by $S$. sclerotiorum, Petri dishes of $15 \mathrm{~cm}$ in diameter, to which PDA osmotically modified by mannitol at $-1.0 \mathrm{MPa}$, according to the description in the literature (Carvalho et al., 2001), were used. Two hundred seeds were distributed on the agar medium in Petri dishes that were kept in a BOD incubator at a temperature of $20^{\circ} \mathrm{C}$ and a 12-hour photoperiod for 96 hours. Following that period, the seeds were removed out of the dishes and dried at room conditions for 48 hours and then stored in a cold and dry chamber until their use.

Evaluation of substrates on the detection of S. sclerotiorum in bean and soybean seeds by the Neon method containing water restriction

For this trial, Petri dishes of $15 \mathrm{~cm}$ in diameter, containing two substrates: solid Neon agar and filter paper moistened with diluted Neon agar were used.

On each dish, forty seeds were distributed randomly, ten of which were artificially inoculated with $S$. sclerotiorum as described before. Two hundred seeds were used per treatment, each dish standing for one replicate. The plates were placed in an incubation chamber at random with a temperature of $20^{\circ} \mathrm{C} \pm 2{ }^{\circ} \mathrm{C}$ and a 12 hour photoperiod for 7 days. Seeds were examined individually for color change as described before. The statistical regression analysis was performed using the software Sisvar.

Evaluation of the effects of the photoperiod on the detection of Sclerotinia sclerotiorum in dry bean and soybean seeds by using the Neon method modified with water restrictors

For this study, the three water restrictors, mannitol (-1.0 $\mathrm{MPa}$ ), $\mathrm{NaCl}$ (-1.0 MPa), PEG (-0.5 MPa) and 2,4-D (acid formulation), were compared and all incorporated to the filter paper substrate (three discs/dish) by the immersion process.

Two hundred seeds per treatment were plated in five dishes of $15 \mathrm{~cm}$ diameter as described before. The incubation conditions were the same as used in the previous experiment. The plates were transferred to the incubation chamber with a temperature of $20^{\circ} \mathrm{C} \pm 2{ }^{\circ} \mathrm{C}$ and a photoperiod of 12 hours light/12 hours dark (alternate) and continuous darkness for 7 days. The evaluation was performed by examining the seeds individually and recording the incidence percentages of $S$. sclerotiorum for all the treatments. The statistical regression analysis was performed using the software Sisvar.

Evaluation of the ability of other fungi commonly associated with dry bean and soybean seeds to change the color of the Neon medium containing water restrictors

One isolate of each of the following fungal species: Alternaria alternata, Botryodiplodia theobromae, $C$. lindemuthianum, C. truncatum, Cladosporium cladosporioides, Dreschlera sp, Fusarium oxysporum f. sp. vasinfectum, F. oxysporum f. sp. phaseoli, Fusarium sp., Isariopsis griseola, Phoma sp, Phomopsis sojae, Rhizoctonia solani, Trichoderma sp, four isolates of Penicillium spp., three isolates of Aspergillus niger, two isolates of A. flavus and one isolate of A. ochraceus, that are commonly found in association with dry bean and soybean seeds were used in this investigation. Most of those fungi were recovered from seeds that were submitted to health testing at the Seed Pathology Laboratory of the Federal University of Lavras (UFLA), state of Minas Gerais in Brazil.

All of the isolates were cultivated initially on PDA medium for $5-7$ days at $20^{\circ} \mathrm{C} \pm 2{ }^{\circ} \mathrm{C}$ and a 12 -hour photoperiod. From the edge of each species colonies, $5 \mathrm{~mm}$ discs were cut and transferred to the center of the dishes containing $15 \mathrm{~mL}$ of Neon medium amended with mannitol (-1.0 MPa), $\mathrm{NaCl}$ (-1.0 MPa), PEG (-0.5 MPa), separately. Five dishes were used per each water restrictor. All the dishes were placed in an 
incubator chamber at $20^{\circ} \mathrm{C}$ and a 12-hour photoperiod for 5-7 days. Observations were made on each dish, for a color change of the substrate around the seeds, as described previously.

\section{Results and Discussion}

Mycelial growth of Sclerotinia sclerotiorum on the substrate of the bromophenol plating method modified with water restrictors (Neon-R)

From the results, statistically analyzed, significant differences among the four isolates of Sclerotinia sclerotiorum were observed in relation to the mycelial growth rate, regardless of the medium composition with mannitol, $\mathrm{NaCl}, \mathrm{PEG}$, or even in plain solid PDA. This result shows a genetic variability in this fungal species based on geographic origin and different hosts (Table 1). This kind of variability of $S$. sclerotiorum may be a consequence of the hyphal anastomosis process, which has been reported in the literature for this organism (Adams and Ayers, 1979; Kohn et al., 1991; Alexopoulos et al., 1996; Glass et al., 2000).

Table 1. Index of mycelial growth (ICM) of four isolates of S. sclerotiorum in the substrate of the Neon method modified with different water restrictors and 2,4-D. (Values in $\mathrm{cm}$ ).

\begin{tabular}{ccccc}
\hline \multirow{2}{*}{ Treatments } & \multicolumn{4}{c}{ Isolates of Sclerotinia sclerotiorum } \\
\cline { 2 - 5 } & ISF & ISS $_{1}$ & ISA & ISS $_{2}$ \\
\hline Neon (Mannitol) & $5.311 \mathrm{Aa}$ & $3.869 \mathrm{Bb}$ & $4.342 \mathrm{Ac}$ & $1.563 \mathrm{Bd}$ \\
Neon (NaCl) & $5.400 \mathrm{Aa}$ & $4.487 \mathrm{Ab}$ & $3.145 \mathrm{Bc}$ & $1.548 \mathrm{Bd}$ \\
Neon (PEG) & $4.634 \mathrm{Ba}$ & $4.234 \mathrm{Ab}$ & $2.896 \mathrm{Bc}$ & $2.249 \mathrm{Ad}$ \\
Plain PDA & $5.270 \mathrm{Aa}$ & $4.460 \mathrm{Ab}$ & $2.980 \mathrm{Bc}$ & $2.110 \mathrm{Ad}$ \\
Standar Neon & $5.420 \mathrm{Aa}$ & $4.190 \mathrm{Ab}$ & $2.870 \mathrm{Bc}$ & $1.120 \mathrm{Cd}$ \\
Neon-S & $0.380 \mathrm{Ca}$ & $0.560 \mathrm{Ca}$ & $0.670 \mathrm{Ca}$ & $0.970 \mathrm{Ca}$ \\
\hline
\end{tabular}

Means with same upper case letter do not differ in columns, and with the same lower case letter do not differ in rows by Scott-Knott test $(\mathrm{P} \leq 0.05)$. (ISF $=\mathrm{Bean}-$ Lavras; ISS $_{1}=$ Soybean-Cristalina; ISA = Cotton-Luziânia; ISS $_{2}=$ Soybean-Lavras).

For one isolate, ISA (cotton), the water restriction promoted by mannitol, provided a stimulus for its mycelial growth (Table 1). It is possible that, in this case, the restrictor was used as a carbon source, as verified and reported by Carvalho et al. (2001) in studies with Colletotrichum lindemuthianum and some water restrictors. According to Coutinho et al. (2001) the stimulating effect of mannitol for other fungi may be related to the use of such a compound as an additional source of energy or to better osmotic adjustment fungal cells by the absorption of solutes and consequent cell extension. This same fact was also observed in studies involving the fungi Colletotrichum truncatum, Phomopsis sojae and S. sclerotiorum on PDA with the water restrictor mannitol (Machado et al., 2001a).

In relation to sodium chloride, the growth of the isolate ISS2 was statistically lower than in plain PDA medium. On the substrate containing PEG6000 growth of the isolate, ISF was also lower compared to the control PDA medium (Table 1). This reduction in the growth rate may be explained by the direct effects of water restriction on the development of some fungal species as observed by Carvalho et al. (2001). According to Mexal and Reid (1973), PEG6000 is a solute that can induce water stress to certain fungi. Although it may be absorbed to a lesser extent, it is not metabolized by fungi as sugar and it is also not considered toxic even at high concentrations. On the other side, the mycelial growth of the fungi Lasiodiplodia theobromae, Fusarium oxysporum $\mathrm{f}$. sp. vasinfectum and $\mathrm{S}$. sclerotiorum were lower in the substrate containing $\mathrm{NaCl}$ compared to mannitol. In that case, Machado et al. (2007) considered that reduction to be the result of the toxic effect of that salt. In the literature, the mycelial growth of fungi on a medium osmotically modified with the addition of ionic and non-ionic solutes is variable, with the differential ability of those organisms to absorb water from the environment. There is a range of water potentials which is suitable for the growth of each species (Carvalho et al., 2001; Costa et al., 2003).

To all the isolates of $S$. sclerotiorum used in this study, there was no statistical difference between the values of the water potential used in the medium Neon modified with mannitol on the rate of mycelial growth. The intermediate values in the gradient of the osmotic potential used either for PEG (-0.5 MPa) and for $\mathrm{NaCl}(-1.0 \mathrm{MPa})$ were favored to the mycelial growth of that fungus.

It is timely to report that in several works (Machado et al., 2004; Machado et al., 2001b), the water restrictors used for different purposes involving fungi like Colletotrichum lindemuthianum, Fusarium oxysporum f.sp. phaseoli and Rhizoctonia solani, Botryodiplodia theobromae, Colletotrichum gossypii, Fusarium moniliforme, 
Cephalosporium acremonium and Diplodia maydis did not interfere with the growth of those organisms.

However, in this work, the substrate of the method Neon-S, in which 2,4-dichlorophenoxyacetic acid was used, the growth rates of all the isolates of S. sclerotiorum were lower, statistically, in relation to the majority of the other treatments, indicating the antifungal effect of 2,4-D acid on this fungus (Table 1, Figure 1B). This negative effect of 2, 4-D has also been observed by Peres et al. (2002), in vitro essays. According to this author, 2, 4-D may cause conidial deformations, reduced sporulation, and small colonies of some fungal species. Consequently, the use of 2,4-D (acid formulation) in seed health testing may be questionable and should be replaced by other alternative means.

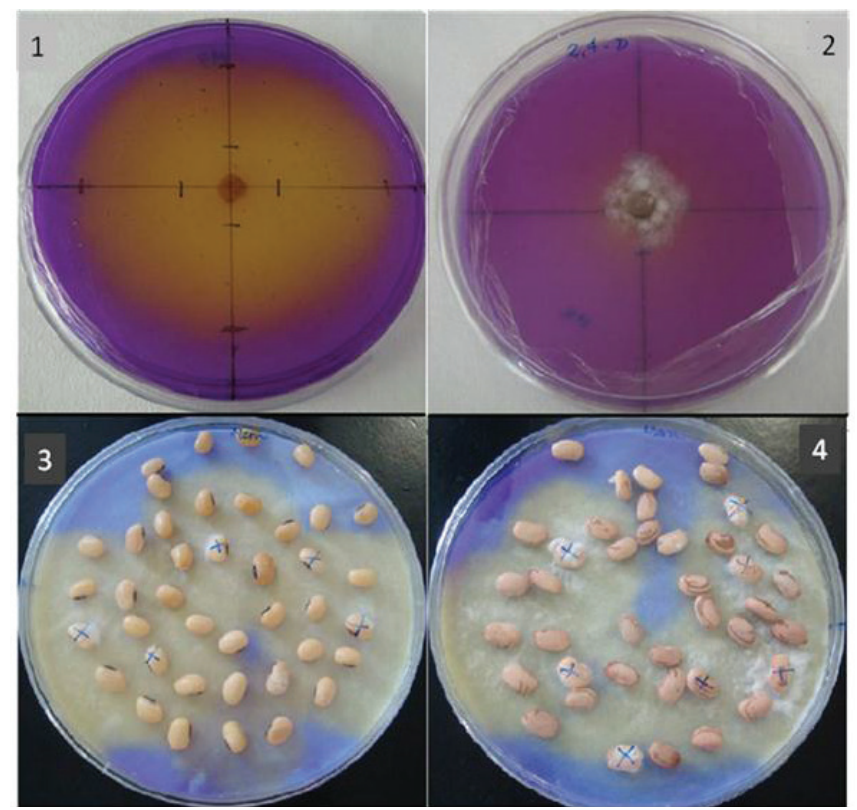

Figure 1. Mycelial growth of isolated ISF of Sclerotinia sclerotiorum with 2 days of incubation by the method Neon containing bromophenol blue, antibiotics and mannitol at -1.0 MPa; 2- Mycelial growth of isolate ISF with 4 days of incubationby the method Neon-S (containing 2,4-D acid); 3 and 4- Incubation of soybean and dry bean seeds by the method Neon with paper substrate containing mannitol at $-1.0 \mathrm{MPa}$ at a temperature of $20^{\circ} \mathrm{C} \pm 2{ }^{\circ} \mathrm{C}$ and continuous darkness.

Effects of water restriction on the seed germination of dry bean and soybean seeds

The partial or entire inhibition of the germination of seeds during the incubation period on the health tests is important in order to ensure the accuracy of this method as well as making it faster and reliable. Thus, the effect of any inhibitor of germination must be first evaluated under conditions in which the test is to be run.

In this work, regardless of the nature of the water restrictors used, a strong effect of the compounds that were used on the seed germination of both dry bean and soybean at the highest osmotic potentials was observed.

In seed health testing, it is acceptable that the size of the seed radicle elongation by the end of the incubation period should not exceed the largest dimension of the non-germinated seeds. In this work, such an inhibition limit was obtained with the use of mannitol and $\mathrm{NaCl}$ at the osmotic potential of -1.0 MPa and with PEG6000 at $-0.5 \mathrm{MPa}$. It is relevant to register that the use of higher osmotic potentials may be unfavorable for $S$. sclerotiorum development (Carvalho et al., 2001; Machado et al. 2001b; Costa et al., 2003). According to a previous experiment, osmotic potentials higher than -1.0 MPa should not be recommended for seed health testing.

In the literature, a reduction in the seed germination rates has been also observed in soybean and dry bean with the use of PEG6000 and $\mathrm{NaCl}$ compounds, as from the osmotic potentials of - $0.2 \mathrm{MPa}$ (McDonald Junior et al., 1988; Rossetto et al.,1997; Moraes et al., 2005).

Detection of Sclerotinia sclerotiorum in dry bean and soybean seeds by the bromophenol plating method modified with water restrictors (Neon- $R$ )

There was no statistical difference between the methods compared for the detection of S. sclerotiorum in the seeds of dry bean and soybean (Table 2).

In relation to the comparison between the efficacy of plain agar and agar paper of the Neon-R method for the detection of $S$. sclerotiorum in soybean seeds, the statistical analysis showed no difference between them as well as between mannitol, $\mathrm{NaCl}$, and 2,4-D acid incorporated to the blotter substrate (Table 2).

It is important to note that in other pathosystems involving the fungi: Colletotrichum gossypi, C. gossypii var. cephalosporioides, Fusarium oxysporum f. sp. vasinfectum and Botryodiplodia theobromae in cotton seeds, artificially inoculated, the same effects were observed with mannitol and $\mathrm{NaCl}$ compounds at $-1.0 \mathrm{MPa}$ osmotic potential, as reported by Machado et al. (2007). This is also true for other pathosystems in rice and beans as reported by Coutinho et al. (2001).

The detection rates of $S$. sclerotiorum in the seeds tested by the Neon method with the addition of PEG6000 to the substrate in the present study were higher when solid agar substrate was used (Table 2). This may be explained by the fast mycelial growth of $S$. sclerotiorum on that substrate, causing a secondary contamination of seeds as it was observed in previous experiment in which PEG6000 was used at the 
osmotic potential of - $0.5 \mathrm{MPa}$. In practice, the incorporation of PEG6000 into paper substrate faces some difficulties in terms of distribution.

The performance and sensitivity of the seed health testing for the detection of $S$. sclerotiorum by the modified Neon method can be affected by the presence of some contaminant organisms, such as Trichoderma spp., Rhizopus spp., Aspergillus and Penicillium spp. Part of those fungi may take over the whole container of seed incubation very quickly and others may change the color of the substrate in a similar way as S. sclerotiorum. For those reasons, plating seeds on blotter substrate impregnated with Neon-R ingredients may be an alternative that should be considered for routine seed analysis for the detection of $S$. sclerotiorum, as reported by Salustiano et al. (2006).

Influence of photoperiod on the detection of Sclerotinia sclerotiorum in dry bean and soybean seeds, using the method Neon-R

In general, the incubation of dry bean and soybean seeds under continuous darkness provided higher percentages of incidence of $S$. sclerotiorum, than under alternating light and dark periods. That was observed for all the restrictors used and for the two isolates of S. sclerotiorum tested (Table 3).

Table 2. Percentages of S. sclerotiorum incidence in dry bean and soybean seeds on different substrate incubation by the method of detection in different treatments of the Neon with water restriction.

\begin{tabular}{|c|c|c|c|c|}
\hline \multirow{4}{*}{$\begin{array}{l}\text { Substrate } \\
\text { Incubation }\end{array}$} & \multicolumn{4}{|c|}{ Treatments } \\
\hline & \multirow{3}{*}{ Neon-S } & \multicolumn{3}{|c|}{ Substrate with water restriction (Neon-R) } \\
\hline & & Mannitol & $\mathrm{NaCl}$ & PEG \\
\hline & & $-1.0 \mathrm{MPa}$ & $-1.0 \mathrm{MPa}$ & $-0.5 \mathrm{MPa}$ \\
\hline \multicolumn{5}{|c|}{ Dry bean } \\
\hline Solid agar & $11.5 \mathrm{Aa}$ & $10.0 \mathrm{Aa}$ & $10.5 \mathrm{Aa}$ & $11.5 \mathrm{Aa}$ \\
\hline Agar paper & $8.5 \mathrm{Aa}$ & $10.5 \mathrm{Aa}$ & $8.5 \mathrm{Aa}$ & $10.5 \mathrm{Aa}$ \\
\hline \multicolumn{5}{|c|}{ Soybean } \\
\hline Solid agar & $16.5 \mathrm{Ab}$ & $13.0 \mathrm{Ab}$ & $13.0 \mathrm{Ab}$ & $41.0 \mathrm{Aa}$ \\
\hline Agar paper & $13.5 \mathrm{Aa}$ & $11.5 \mathrm{Aa}$ & $9.0 \mathrm{Aa}$ & $11.0 \mathrm{Ba}$ \\
\hline
\end{tabular}

Means with same upper case letter do not differ in columns, and with the same lower case letter do not differ in rows by Scott-Knott test (P $\leq 0.05)$, in each crop.

Table 3. Percentage incidence of S. sclerotiorum in dry bean and soybean seeds under different light regimes by the method of detection in different treatments of the Neon with water restriction.

\begin{tabular}{|c|c|c|c|c|}
\hline \multirow{4}{*}{ Incubation photoperiods } & \multicolumn{4}{|c|}{ Treatments } \\
\hline & \multirow{3}{*}{ Neon-S } & \multicolumn{3}{|c|}{ Neon with water restriction } \\
\hline & & Mannitol & $\mathrm{NaCl}$ & PEG \\
\hline & & $-1.0 \mathrm{MPa}$ & $-1.0 \mathrm{MPa}$ & $-0.5 \mathrm{MPa}$ \\
\hline \multicolumn{5}{|c|}{ Bean } \\
\hline Continuous darkness & $25.5 \mathrm{Ab}$ & $21.0 \mathrm{Ab}$ & $22.0 \mathrm{Ab}$ & $31.0 \mathrm{Aa}$ \\
\hline $12 \mathrm{~h}$ light $/ 12 \mathrm{~h}$ dark & $8.5 \mathrm{Ba}$ & $10.5 \mathrm{Ba}$ & $8.5 \mathrm{Ba}$ & $10.5 \mathrm{Ba}$ \\
\hline \multicolumn{5}{|c|}{ Soybean } \\
\hline Continuous darkness & $19.4 \mathrm{Ab}$ & $35.5 \mathrm{Aa}$ & $27.0 \mathrm{Ab}$ & $21.5 \mathrm{Ab}$ \\
\hline $12 \mathrm{~h}$ light $/ 12 \mathrm{~h}$ dark & $13.5 \mathrm{Aa}$ & $11.5 \mathrm{Ba}$ & $9.0 \mathrm{Ba}$ & $11.0 \mathrm{Ba}$ \\
\hline
\end{tabular}

Means with same upper case letter do not differ in columns, and with the same lower case letter do not differ in rows by Scott-Knott test (P $\leq 0.05)$, in each crop.

The use of an alternating light and dark regime during the incubation of seeds is aimed at stimulating the fungal sporulation of some fungi (Neergaard, 1977). In the case of $S$. sclerotiorum, such stimulus is unnecessary because that species does not form conidia during the incubation period of the health testing. Examples of species in which sporulation is stimulated under light and dark alternation are: Alternaria zinniae, A. brassica, Fusarium solani, Bipolaris oryzae and Drechslera sorikiniana (Teixeira et al., 2001).

The highest rates of $\mathrm{S}$. sclerotiorum incidences under continuous darkness may be explained considering the adverse effect of the darkness environment for some fungal species, which under a light and dark regime could affect the normal development of $S$. sclerotiorum. Another hypothesis could be raised to explain such results and that remains open for further investigations. 
From those results, it turns out that the Neon-R method with incubation under continuous darkness is a reliable and a more economic procedure for the detection of S. sclerotiorum in dry bean and soybean seeds, as illustrated in Figures 1 $\mathrm{C}$ and $1 \mathrm{D}$.

Behavior of fungi commonly associated with dry bean and soybean seeds by the method Neon-R

The color change from blue to yellow which is the principle of the method of the agar substrate Neon, is the result of the reduction in $\mathrm{pH}$ due to acid production by $S$. sclerotiorum, in the presence of bromophenol blue, which is an indication of acid production in the substrate (Domsch et al. 1980; Steadman et al., 1994). The whole process involving the chemical bases of that color reaction is well explained by those authors in their publications. Specifically for S. sclerotiorum, the color change in the substrate by the Neon method is ascribed to the oxalic acid production by the fungus. This change is initiated from the 24 hours of incubation, increased gradually with the development of the fungus (Peres et al., 2002).

In this work, the color change induced by $S$. sclerotiorum was similar among the three water restrictor compounds. Among the fungi tested, only Aspergillus niger and one species of Penicillium were able to change the color of the Neon substrate from blue to yellow. In the literature, other fungi like Rhizopus stolonifer and Sclerotium rolfsii that produce acids are also able to change the color of the substrate of the Neon method (Domsch et al., 1980; Peres et al., 2002).

In practical terms, the change in color of the substrate of the method Neon by the species of Aspergillus niger, Penicillium, and Rhizopus should not be considered a limiting factor for the selective detection of $S$. sclerotiorum in the seeds of host plants, since the morphological characteristics of those fungi are easily distinguished from the characteristics of S. sclerotiorum, such as the mycelial appearance and, mainly, the formation of sclerotia at the end of the incubation period.

\section{Conclusions}

The incorporation of mannitol at $-1.0 \mathrm{MPa}$ into the substrate of the bromophenol plating method, Neon, for the detection of $S$. sclerotiorum in dry bean and soybean seeds provided results that are comparable to the 2,4-D bromophenol plating method.

Incubation of dry bean and soybean seeds by the bromophenol plating method under continuous darkness showed to be more efficient in the detection of S. sclerotiorum than the incubation of the seeds under alternating cycles of light.

The modification of the bromophenol plating method
(Neon-S) by replacing 2, 4-D acid by mannitol so as to inhibit seed germination during the incubation period, with seed incubation under continuous darkness, is advantageous for adoption in routine seed analysis laboratories.

\section{Acknowledgements}

We would like to thank CNPq and FAPEMIG for the support that was provided for this research.

\section{References}

ADAMS, P.B.; AYERS, W.A. Ecology of Sclerotinia species. Phytopathology, v.69, n.8, p.896-899, 1979.

ALEXOPOULOS, C.J.; MIMS, C.W.; BLACKWELL, M. Introductory mycology. 4.ed. New York: J.Wiley, v.1, 1996. 488p.

BOLAND, G. J.; HALL, R. Index of host plants of Sclerotinia sclerotiorum Canadian Journal of Plant Pathology, v.16, p.93-108, 1994.

CARVALHO, J.C.B.; MACHADO, J.C.; VIEIRA, M.G.G.C. Crescimento micelial de Colletotrichum lindemuthianum em relação à restrição hídrica do substrato agarizado. Ciência e Agrotecnologia, v.25, n.4, p.999-1005, 2001.

COSTA, M.L.N.; MACHADO, J.C.; GUIMARÃES, R.M.; POZZA, E.A.; ORIDE, D. Inoculação de Fusarium oxysporum f. sp. phaseoli em sementes de feijoeiro através de restrição hídrica. Ciência e Agrotecnologia, v.27, n.5, p.1023-1030, 2003. http://www.scielo.br/pdf/cagro/v27n5/a08v27n5.pdf

COUTINHO, M.C.; MACHADO, J.C; VIEIRA, M.G.G.C.; GUIMARÃES, R.M.; FERREIRA, D.F. Uso da restrição hídrica na inibição ou retardamento da germinação de sementes de arroz e feijão submetidas ao teste de sanidade em meio agar-água. Revista Brasileira de Sementes, v.23, n.2, p.127-135, 2001. http://www.abrates.org.br/revista/artigos/2001/v23n2/artigo19.pdf

DOMSCH, K.H.; GAMS, W.; ANDERSON, T.H. Compendium of soil fungi. London: Academic, v.1, 1980. 859p.

FERREIRA, D. F. Sisvar: versão 4.2. Lavras: UFLA, 2003.

GLASS, N.L.; JACOBSEN, D.; SHIU, P.K. The genetics of hyphal fusion and vegetative incompatibility in filamentous ascomycetes. Annual Review of Genetics, v.34, p.165-186, 2000. http://www.annualreviews.org/doi/ abs/10.1146/annurev.genet.34.1.165? journalCode $=$ genet

KOHN, L.M.; STASOVSKI, E.; CARBONE, I.; ROYER, J.; ANDERSON, J.B. Mycelial incompatibility and molecular markers identify genetic variability in field populations of Sclerotinia sclerotiorum. Phytopathology, v.81, p.480-405, 1991. http://www.apsnet.org/publications/phytopathology/ backissues/Documents/1991_Articles/Phyto81n04_480.pdf

MACHADO, A.Q.; MACHADO, J.C.; VIEIRA, M.G.G.C.; CASSETARI NETO, D.; SOUZA, M.V. Potencial do uso da restrição hídrica em testes de sanidade de sementes de algodoeiro. Fitopatologia Brasileira, v.32, n.5, p.408-414, 2007. http://www.scielo.br/pdf/fb/v32n5/v32n5a06.pdf

MACHADO, J.C.; OLIVEIRA, J.A.; VIEIRA, M.G.G.C. Inoculação artificial de sementes de soja por fungos, utilizando manitol. Revista Brasileira de Sementes, v.23, n.2, p.95-101, 2001a. http://www.abrates.org.br/revista/ artigos/2001/v23n2/artigo13.pdf 
MACHADO, J.C.; OLIVEIRA, J.A.; VIEIRA, M.G.G.C.; ALVES, M. C. Uso da restrição hídrica na inoculação de fungos em sementes de algodoeiro. Revista Brasileira de Sementes, v.26, n.1, p.62-67, 2004. http://www.scielo. br/pdf/rbs/v26n1/a10v26n1.pdf

MACHADO, J.C.; OLIVEIRA, J.A.; VIEIRA, M.G.G.C.; ALVES, M.C. Uso da restrição hídrica na inoculação de fungos em sementes de milho. Revista Brasileira de Sementes, v.23, n.2, p.88-94, 2001b. http://www.abrates.org.br/ revista/artigos/2001/v23n2/artigo12.pdf

McDONALD JUNIOR, M.B.; VERTUCCI, C.W.; ROOS, E.E. Soybean seed imbibition: water absortion by seed parts. Crop Science, v.28, n.6, p.993-997, 1988. https://www.agronomy.org/publications/cs/abstracts/28/6/ CS0280060993

MEXAL, J.; REID, C.P.P. The growth of selected mycorrhizal fungi in response to induced water stress. Canadian Journal of Botany, v.51, n.9, p.1579-1588, 1973. http://www.nrcresearchpress.com/doi/abs/10.1139/b73201\#.UL p6qyvmuI

MICHEL, B.E.; RADCLIFFE, D. A computer program relating solute potential to solution composition for five solutes. Agronomy Journal, v.87, n. 1, p. 126-130, 1995 .

MORAES, G.A.F.; MENEZES, N.L.; PASQUALLI, L.L. Comportamento de sementes de feijão sob diferentes potenciais osmóticos. Ciência Rural, v.35, n.4, p.776-780, 2005. http://www.scielo.br/pdf/\%0D/cr/v35n4/a04v35n4.pdf

NAPOLEÃO, R.; NASSER, B.L.C.; LOPES, C.A.; CAFÉ FILHO, A.C. Neon-S, novo meio para deteç̧ão de Sclerotinia sclerotiorum em sementes. Summa Phytopathologica, v.32, n.2, p.180-183, 2006. http:/www.scielo.br/ $\mathrm{pdf} / \mathrm{sp} / \mathrm{v} 32 \mathrm{n} 2 / \mathrm{v} 32 \mathrm{n} 2 \mathrm{a} 14 . \mathrm{pdf}$
NEERGARD, P. Seed pathology. London: Macmillan, 1977. 839p.

PERES, A.P.; NASSER, L.C.B.; MACHADO, J.C. Use of semi-seletive media for detection of Sclerotinia sclerotiorum on bean and soybean seeds. Fitopatologia Brasileira, v.27, n.2, p.123-127, 2002. http://www.scielo.br/ scielo. php?pid=S0100-1582002000200001\&script=sci_arttext

ROSSETTO, C.A.V.; NOVEMBRE, A.D.L.C.; MARCOS-FILHO, J.; SILVA W.R.; NAKAGAWA, J.Efeito da disponibilidadehídrica do substrato, da qualidade fisiológica e do teor deágua inicial das sementes de soja no processo de germinação. Scientia Agricola, v.54, n.1-2, p.97-105, 1997. http://www.scielo.br/scielo. php?script=sci_arttext\&pid=S010390161997000100014\&lng=en\&tlng=pt. http://dx.doi.org/10.1590/S0103-90161997000100014.

SALUSTIANO, M.E.; MACHADO, J.C.; PITTIS, J.E. Comparação de dois métodos de sanidade na detecção de Alternaria helianthi em sementes de girassol. Fitopatologia Brasileira, v.31, n.1, p.322-323, 2006. http://www. scielo.br/pdf/fb/v31n3/a20v31n3.pdf

STEADMAN, J.R.; MARCINKOWSKA, J.; RUTLEDGE，S. A semiselective medium for isolation of Sclerotinia sclerotiorum. Canadian Journal of Plant Pathology, v.16, n.2, p.68-70, 1994. http://www.tandfonline.com/ doi/abs/10.1080/07060669409500791

TEIXEIRA, H.; CHITARRA, L.G.; ARIAS, S.M.S.; MACHADO, J.C. Efeito de diferentes fontes de luz no crescimento e esporulação in vitro de fungos fitopatogênicos. Ciência e Agrotecnologia, v.25, n.6, p.1314-1320, 2001. http://www.editora.ufla.br/_adm/upload/revista/25-6-2001_08.pdf 